\title{
Purification and Characterization of an Endoinulinase from Xanthomonas campestris pv. phaseoli KM 24 Mutant
}

\author{
Kameshnee Naidoo§, Ajit Kumar§, Vikas Sharma, Kugen Permaul and Suren Singh* \\ Department of Biotechnology and Food Technology, Faculty of Applied Sciences, \\ Durban University of Technology, P.O. Box 1339, Durban 4001, Republic of South Africa \\ Received: September 18, 2014 \\ Accepted: February 23, 2015
}

\begin{abstract}
Summary
An extracellular endoinulinase from Xanthomonas campestris pv. phaseoli KM 24 mutant was purified to homogeneity by gel filtration chromatography and showed a specific activity of $119 \mathrm{U} / \mathrm{mg}$. The optimum $\mathrm{pH}$ and temperature of the purified enzyme were found to be 6.0 and $50{ }^{\circ} \mathrm{C}$, respectively. The enzyme was stable up to $60^{\circ} \mathrm{C}$, retaining $60 \%$ of residual activity for $30 \mathrm{~min}$, but inactivated rapidly above $60^{\circ} \mathrm{C}$. The enzyme was found to be stable at $\mathrm{pH}=6-9$ when it retained $100 \%$ of its residual activity. The Lineweaver-Burk plot showed that the apparent $K_{\mathrm{m}}$ and $v_{\max }$ values of the inulinase when using inulin as a substrate were $1.15 \mathrm{mg} / \mathrm{mL}$ and $0.15 \mu \mathrm{M} / \mathrm{min}$, respectively, whereas the $k_{\text {cat }}$ value was found to be $0.145 \mathrm{~min}^{-1}$. The calculated catalytic efficiency of the enzyme was found to be 0.126 $(\mathrm{mg} \cdot \mathrm{min}) / \mathrm{mL}$. The purified inulinase can be used in the production of high fructose syrups.
\end{abstract}

Key words: Xanthomonas campestris pv. phaseoli KM 24 mutant, inulinases, endoinulinases, exoinulinases, fructooligosaccharides, inulin

\section{Introduction}

Inulin is considered as a renewable raw material in the production of fructose syrup and fructooligosaccharides (FOS) (1) and hence, enzyme inulinases are widely used in food and pharmaceutical industries (2). Microbial inulinases can be classified into exo- and endo-acting enzymes according to their modes of action on inulin. Endoinulinases (2,1- $\beta$-D-fructan fructanohydrolase; EC 3.2. 1.7) are specific for inulin and hydrolyse the internal $\beta$-2,1-fructofuranosidic linkages to yield inulooligosaccharides such as inulotriose, inulotetraose and inulopentaose as their main products. Exoinulinases $(\beta$-D-fructan fructohydrolase; EC 3.2.1.80) successively cleave off terminal fructose units from the non-reducing end of inulin, and also hydrolyse sucrose and raffinose $(3,4)$. Therefore, inulinases could be used for production of either high fructose syrups by exo-enzymatic hydrolysis of inulin with D-fructose content over $95 \%$, or for production of oligofructoside syrups by endo-enzymatic hydrolysis (5). Inulinases are produced by a few bacteria (Xanthomonas sp., Bacillus sp., Pseudomonas sp., Thermotoga sp., Bifidobacterium sp., Geobacillus sp. and Clostridium sp.), fungi (Aspergillus sp., Penicillium sp. and Fusarium sp.) and yeast (Kluyveromyces sp.) (4). The optimization of the nutritional and growth parameters of X. campestris pv. phaseoli for the production of endoinulinase using the submerged and solid-state cultivations has been reported earlier (6). The rate of endoinulinase and FOS production was further enhanced through ethylmethanesulphonate (EMS) mutagenesis of $X$. campestris pv. phaseoli and the mutant was named X. campestris pv. phaseoli KM 24 (Xcp KM 24) (7). The present study, therefore, focuses on the purification and characterization of endoinulinase from Xcp KM 24 using gel filtration chromatography.

\footnotetext{
*Corresponding author: Phone: +27 31373 5321; Fax: +27 31308 5351; E-mail: singhs@dut.ac.za

sBoth authors contributed equally to this work
} 


\section{Materials and Methods}

\section{Bacterial strain}

Strain Xanthomonas campestris pv. phaseoli was obtained from the culture collection of the Department of Microbiology at the University of KwaZulu-Natal, Durban, South Africa. The strain was improved by chemical mutagenesis using EMS as described earlier (8) with slight modifications. Optimized medium was used to test the mutants for their ability to produce inulinase and FOS. The strain was named Xanthomonas campestris pv. phaseoli KM 24 (Xcp KM 24) (7) and stored as $70 \%$ glycerol stocks at $-70{ }^{\circ} \mathrm{C}$.

\section{Endoinulinase production by Xanthomonas campestris pv. phaseoli KM 24}

For the production of endoinulinase, the mutant Xcp KM 24 was inoculated into $50 \mathrm{~mL}$ of the inulinase production medium (IPM) containing (in $\mathrm{g} / \mathrm{L}$ ): inulin 20, yeast extract 20, $\left(\mathrm{NH}_{4}\right)_{2} \mathrm{HPO}_{4} 5, \mathrm{NH}_{4} \mathrm{H}_{2} \mathrm{PO}_{4} 2, \mathrm{MnCl}_{2} 0.5, \mathrm{KCl} 0.5$, $\mathrm{MgSO}_{4} 0.5$ and $\mathrm{FeSO}_{4} 0.01$ (pH=7.0) (9). Pure inulin prepared from chicory roots was obtained from Sigma-Aldrich, St. Louis, MO, USA. IPM was dispensed into 250-mL Erlenmeyer flasks and inoculated with $10 \%$ (by volume) of a 16-hour-old Xcp KM 24 culture and incubated at $37{ }^{\circ} \mathrm{C}$ for $120 \mathrm{~h}$ with shaking at $150 \mathrm{rpm}$. Samples were withdrawn every $12 \mathrm{~h}$, centrifuged at $10000 \times g$ and the supernatant was used for determining inulinase activity $(6,7)$.

\section{Determination of inulinase activity}

Inulinase activity was determined by quantifying the amount of reducing sugars released from inulin as described earlier (10). The reaction mixture containing 0.1 $\mathrm{mL}(10 \mu \mathrm{M})$ of crude enzyme extract and $0.9 \mathrm{~mL}$ of sodium acetate buffer $(100 \mathrm{mM}, \mathrm{pH}=5.5)$ was incubated at 50 ${ }^{\circ} \mathrm{C}$. The reaction was started by adding $1 \mathrm{~mL}$ of $2 \%$ inulin and allowed to react for $20 \mathrm{~min}$. One inulinase unit (IU) was defined as the amount of enzyme that produces one micromole of fructose equivalent per minute under standard assay conditions.

\section{Concentration and purification of inulinase}

One litre of inulinase production culture medium supernatant was sequentially subjected to precipitation with ammonium sulphate from 20 to $100 \%$ at intervals of $20 \%$ at $4{ }^{\circ} \mathrm{C}$ for $16 \mathrm{~h}$. The pellets were collected by centrifugation, dissolved in $5 \mathrm{~mL}$ of sodium phosphate buffer $(\mathrm{pH}=7)$ and dialysed through the 12-kDa cut-off dialysis membrane from Sigma-Aldrich against the same buffer. The fractions of 40,60 and $80 \%$ showed inulinase activity and they were pooled together. The sample was concentrated using ultrafiltration spin column (Amicon Ultra-15 Centrifugal Filter Unit, molecular mass cut-off $30 \mathrm{kDa}$, cat. no. UFC903024, Merck KGaA, Darmstadt, Germany) and $1 \mathrm{~mL}$ of enzyme sample $(1 \mathrm{mg} / \mathrm{mL})$ was loaded into approx. $75-\mathrm{mL}$ Sephadex G-100 column $(40 \mathrm{~cm} \times 0.75 \mathrm{~cm}$; GE Healthcare Life Sciences, Little Chalfont, UK) and eluted with $50 \mathrm{mM}$ phosphate buffer at a flow rate of 1 $\mathrm{mL} / \mathrm{min}$. Fractions of $4 \mathrm{~mL}$ were collected and assayed for protein content (at $280 \mathrm{~nm}$ ) and inulinase activity as described above (data not shown). The fractions showing inulinase activity were pooled together and concentrated again by passing the samples through ultrafiltration spin column in the centrifuge at the speed of $6500 \times g$ for 15 min. A small volume of fractions $(200 \mu \mathrm{L})$ was precipitated with $800 \mu \mathrm{L}$ of chilled acetone to check the purity and homogeneity of the protein by subjecting it to $12 \%$ SDS-PAGE (11) run on constant potential difference of $100 \mathrm{~V}$. The gel was stained with Coomassie Brilliant Blue R-250 (CBB R-250) and the protein content was determined as previously described by Bradford (12) using bovine serum albumin (BSA) as standard.

\section{Determination of optimum $\mathrm{pH}$ and temperature of purified inulinase}

In order to determine the optimum $\mathrm{pH}$ of the purified inulinase, $0.5 \%$ (by mass per volume) inulin substrate solutions were prepared in the following buffers (100 mM): citrate buffer ( $\mathrm{pH}=4-6)$, sodium phosphate buffer $(\mathrm{pH}=7)$, Tris- $\mathrm{HCl}(\mathrm{pH}=8$ and 9) and glycine- $\mathrm{NaOH}$ $(\mathrm{pH}=10)$. The enzyme $(1 \mu \mathrm{M})$ was incubated with the substrate at $50{ }^{\circ} \mathrm{C}$ for $20 \mathrm{~min}$. To determine the optimum temperature, the enzyme $(1 \mu \mathrm{M})$ was incubated with the substrate prepared in the optimum $\mathrm{pH}$ buffer. The assay mixture containing $50 \mu \mathrm{L}(1 \mu \mathrm{M})$ of the enzyme solution and $950 \mu \mathrm{L}$ of the substrate solution in sodium phosphate buffer $(100 \mathrm{mM}, \mathrm{pH}=7)$ was incubated at temperatures ranging from 25 to $90^{\circ} \mathrm{C}$.

\section{Determination of $\mathrm{pH}$ and temperature stability}

The $\mathrm{pH}$ stability of the enzyme was determined by incubating $1 \mathrm{~mL}(10 \mu \mathrm{M})$ of the enzyme at $\mathrm{pH}=4-9$ at 50 ${ }^{\circ} \mathrm{C}$. Aliquots of $100 \mu \mathrm{L}$ were removed at time intervals of $0,10,20,30,60,90,120,150$ and $180 \mathrm{~min}$, and assayed by incubating with $900 \mu \mathrm{L}$ of inulin substrate as mentioned above. Temperature stability of the enzyme was determined by incubating inulinase $(10 \mu \mathrm{M})$ at different temperatures i.e. $50-90{ }^{\circ} \mathrm{C}$ at the intervals of $10{ }^{\circ} \mathrm{C}$. The aliquots of $100 \mu \mathrm{L}$ were removed at time intervals of 0,10 , 20, 30, 60, 90, 120, 150 and $180 \mathrm{~min}$, and assayed for inulinase activity. For determination of temperature stability of the purified enzyme, the substrate was prepared in sodium phosphate buffer $(100 \mathrm{mM}, \mathrm{pH}=6)$. The final concentration of the enzyme in the assay reaction mixture was $1 \mu \mathrm{M}$.

\section{Determination of $K_{m}, v_{\max }$ and $k_{\text {cat }}$ values}

The initial rate of enzymatic activity was measured to determine kinetic parameters for the substrate hydrolysis. The Michaelis-Menten constant $\left(K_{\mathrm{m}}\right)$ was determined from the Lineweaver-Burk plot by applying the Michaelis-Menten equation (Eq. 1). The activity of inulinase was measured using Lineweaver-Burk plot analysis, by incubating it at substrate concentrations from $0.2-15 \mu \mathrm{g} / \mathrm{mL}$ in sodium phosphate buffer ( $\mathrm{pH}=6$ and $50{ }^{\circ} \mathrm{C}$ ). The reciprocal values of the rate of substrate hydrolysis $(1 / v)$ were plotted against the reciprocal values of the substrate concentrations $(1 /[\mathrm{S}])$, and the $K_{\mathrm{m}}$ values were determined by fitting the resulting data using ORIGIN v. 8 Pro software (OriginLab Corporation, Northampton, MA, USA). The $v_{\max }$ was also determined from the Lineweaver-Burk plot. The catalytic constant of the enzyme substrate reaction 
$\left(k_{\text {cat }}\right)$, also referred to as the turnover number, represents the number of reactions catalysed by each active site per unit time and was determined by Eq. 2, while the catalytic efficiency of the enzyme was calculated by using Eq. 3:

$$
\begin{gathered}
1 / v_{0}=\left(K_{\mathrm{m}} / v_{\max }\right)(1 /[\mathrm{S}])+1 / v_{\max } \\
k_{\text {cat }}=v_{\text {max }} /[\mathrm{E}]_{\mathrm{t}} \\
\text { Catalytic efficiency }=k_{\text {cat }} / K_{\mathrm{m}}
\end{gathered}
$$

where $[\mathrm{S}]$ is the substrate concentration, $v_{0}$ is the initial velocity, $v_{\max }$ is the maximum velocity, $K_{\mathrm{m}}$ is the Michaelis-Menten constant and $[\mathrm{E}]_{\mathrm{t}}$ is the total enzyme concentration $(1 \mu \mathrm{M})$.

\section{Thin layer chromatography to determine the catalytic nature of the inulinase}

The products of inulin hydrolysis with purified inulinase from Xcp KM 24 strain were determined by performing the thin layer chromatography (TLC). The enzyme reaction $(0.5 \mathrm{~mL}$ of purified inulinase $(1 \mu \mathrm{M})$ and $0.5 \mathrm{~mL}$ of inulin $(0.5 \%$, by mass per volume $)$ ) was carried out at $50{ }^{\circ} \mathrm{C}$ and $\mathrm{pH}=6.0$ for $24 \mathrm{~h}$. Precoated TLC plates (Silica gel 60, Merck, Darmstadt, Germany) spotted with samples were developed with the solvent system, ethyl acetate/acetic acid/2-propanol/formic acid/water (25:10:5: 1:15, by volume). Sucrose (Sigma-Aldrich), glucose (Sigma-Aldrich), fructose (Merck), 1-kestose, 1,1-kestotetraose and 1,1,1-kestopentaose (Megazyme, Wicklow, Ireland) were used as standards. The TLC plates were developed using detection reagent containing $1 \%$ (by mass per volume) orcinol and $10 \%$ (by volume) sulphuric acid in absolute ethanol and heating them at $100{ }^{\circ} \mathrm{C}$ for $5 \mathrm{~min}$ to detect sugars (7).

\section{Statistical analysis}

All the kinetic parameters were determined by fitting the data using ORIGIN v. 8 Pro software (OriginLab Corporation). The assays for the kinetic analysis and rate constant determinations were carried out in triplicate, and the average value was considered throughout. The p-value lower than 0.05 was considered statistically significant.

\section{Results and Discussion}

\section{Purification of inulinase}

The present study reports the purification and characterization of an endoinulinase from Xcp KM 24, a mutant strain of Xanthomonas campestris pv. phaseoli. The endoinulinase produced by Xcp KM 24 was purified to homogeneity in two steps, ammonium sulphate precipi- tation and Sephadex G-100 column chromatography with $77 \%$ yield, and had a specific activity of $174.74 \mathrm{U} / \mathrm{mg}$. Table 1 shows the summary of the enzyme purification and the total yield. The final enzyme preparation was homogeneous on SDS-PAGE, with a molecular mass of $55 \mathrm{kDa}$ (Fig. 1). A considerable variation in molecular mass of inulinases has been reported earlier, e.g. Arthrobacter sp. (75 kDa), Bacillus stearothermophilus KP1289 (54 kDa), Aspergillus candidus (54 kDa), Penicillium sp. TN-88 (68 kDa), Kluyveromyces marxianus var. bulgaricus (57 kDa) and Streptomyces sp. (45 kDa) (13-18). Five exoinulinases from Aspergillus ficuum showed the same molecular mass of 74 $\mathrm{kDa}$ and three endoinulinases had a molecular mass of 64 $\mathrm{kDa}$ (19). A new thermophilic inulinase-producing strain Bacillus smithii $\mathrm{T} 7$, which grows optimally at $60^{\circ} \mathrm{C}$, was isolated from soil samples with a medium containing inulin as a sole carbon source. Maximum inulinase yield of $135.2 \mathrm{IU} / \mathrm{mL}$ was achieved with medium $\mathrm{pH}=7.0$, containing $2.0 \%$ inulin. The purified inulinase from the extracellular extract shows endoinulinolytic activity (20). A. ficuum JNSP5-06 produces five enzymes with molecular masses of 70, 40, 46, 34 and $31 \mathrm{kDa}$ (21). A. ficuum JNSP506 endoinulinase expressed in Escherichia coli exhibited $M$ of $60 \mathrm{kDa}(22)$, which is in contrast to the above study. The crystal structural analysis of inulinase from $A$. ficuum JNSP5-06 at $1.5 \AA$ and its comparison with other glycoside hydrolase family 32 (GH32) enzymes reveal the presence of an extra pocket in the INU2 catalytic site, formed by two loops and the conserved motif W-M(I)-N-D(E)P-N-G. This cavity could explain the endo-activity of the enzyme,

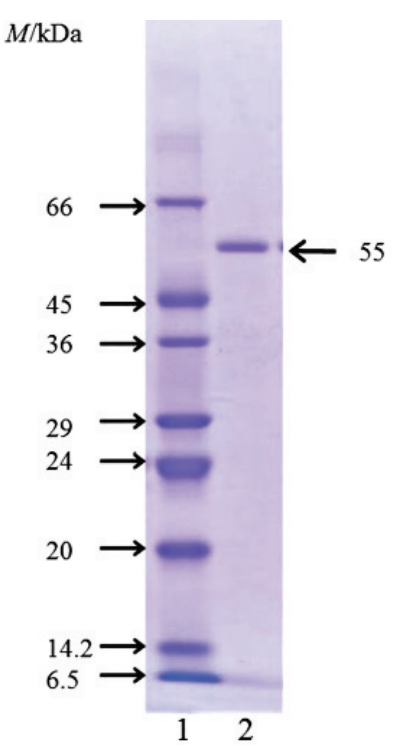

Fig. 1. SDS-PAGE of purified inulinase. Lane 1: molecular mass

\begin{tabular}{|c|c|c|c|c|c|}
\hline Purification step & $\frac{\gamma(\text { protein })}{\mathrm{mg} / \mathrm{mL}}$ & $\frac{\text { Endoinulinase activity }}{\mathrm{U} / \mathrm{mL}}$ & $\frac{\text { Yield }}{\%}$ & $\frac{\text { Specific activity }}{\mathrm{U} / \mathrm{mg}}$ & Purification factor \\
\hline Crude culture filtrate & 0.217 & 22.12 & 100 & 102 & 1 \\
\hline$\left(\mathrm{NH}_{4}\right)_{2} \mathrm{SO}_{4}$ precipitation & 0.179 & 18.76 & 85.2 & 104.8 & 1.02 \\
\hline Sephadex G-100 & 0.097 & 16.95 & 77 & 174.74 & 1.74 \\
\hline
\end{tabular}
marker, lane 2: purified endoinulinase

Table 1. Summary of the purification and yield of endoinulinase from Xanthomonas campestris pv. phaseoli KM 24 supernatant 
the critical role of Trp40, and particularly the cleavage at the third unit of the inulin (-like) substrates (23). Most of the inulinases from fungi have been reported to have a molecular mass above $50 \mathrm{kDa}(24)$. The molecular mass of the purified inulinase from the supernatant of the cell culture of the marine yeast Cryptococcus aureus G7a was estimated to be $60 \mathrm{kDa}(25)$, while the molecular mass of the purified inulinase from Pichia guilliermondii strain 1 was estimated to be $50 \mathrm{kDa}(26)$. However, it has been reported that the $M$ of extracellular inulinase from the terrestrial yeast Kluyveromyces fragilis is $250 \mathrm{kDa}$. The molecular mass of the purified exoinulinase from bacteria was estimated to be approx. $54 \mathrm{kDa}(27,28)$. This suggests that molecular mass of the exoinulinases from bacteria is almost the same as of the exoinulinases from yeasts. $K$. marxianus CBS 6556 inulinase (rKmINU) gene expressed in methylotrophic host Pichia pastoris showed a specific activity of $2714 \mathrm{U} / \mathrm{mg}$ (29), which is 12-fold higher than those of other inulinases described previously. It displayed excellent stability from 30 to $50{ }^{\circ} \mathrm{C}$ and $\mathrm{pH}=3.0$ 5.0, and its half-life was over $96 \mathrm{~h}$ under these conditions. Moreover, rKmINU saccharified Jerusalem artichoke tuber juice effectively (29). A 79.8-kDa endoinulinase gene (enIA) from Arthrobacter sp. S37 overexpressed in Yarrowia lipolytica Po1h showed endoinulinase and specific endoinulinase activities of $16.7 \mathrm{U} / \mathrm{mL}$ and $93.4 \mathrm{U} / \mathrm{mg}$, respectively (30). From Lactobacillus casei IAM1045, levH1 gene encoding an inulinase was cloned and sequenced, and structure-function relationship was investigated by site-directed mutagenesis (31). This gene product belongs to GH32 enzyme group, and is composed of four domains. From the catalytic domain of levH1 gene, the 8 th motif was newly found in the $\beta$-sandwich module, and the necessity of its D683 residue for catalysis was confirmed. LevH1 was found to be an exo-type inulinase producing exclusively fructose, and the knockout of levH1 resulted in the loss of the bacterial ability to catabolize inulin for growth (31). An inulinase of $M=66 \mathrm{kDa}$ from a marine bacterium Bacillus cereus MU-31 is also reported to have an activity of $96 \mathrm{U} / \mathrm{mL}$ (32).

\section{Optimum temperature and thermostability of inulinase}

The inulinase activity measured as a function of temperature from 30 to $90{ }^{\circ} \mathrm{C}$ shows that the activity of the

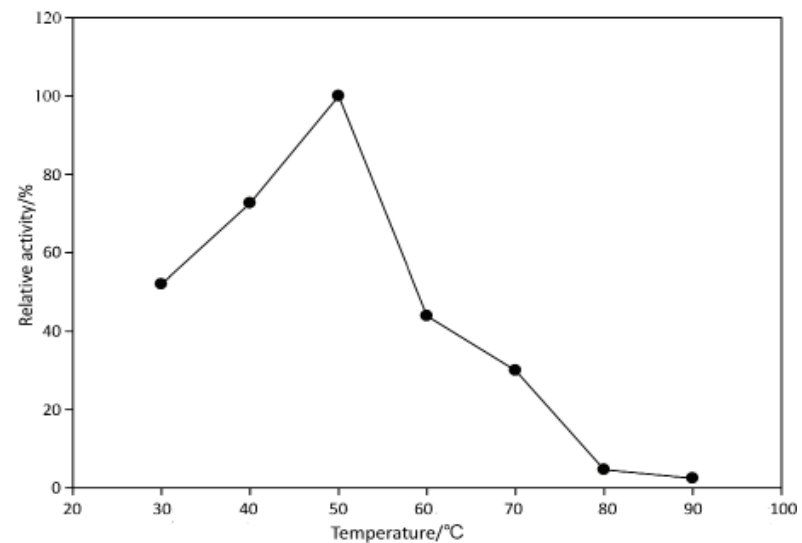

Fig. 2. Optimum temperature for the purified endoinulinase determined by performing the standard enzyme assays at different temperatures in $100 \mathrm{mM}$ citrate buffer $(\mathrm{pH}=6)$ enzyme was the highest at $50{ }^{\circ} \mathrm{C}$ (Fig. 2). The enzyme is stable at up to $60{ }^{\circ} \mathrm{C}$, retaining over $60 \%$ activity for 30 min, but inactivated rapidly at higher temperatures. At 90 ${ }^{\circ} \mathrm{C}$, the enzyme lost its complete activity within $10 \mathrm{~min}$ (Fig. 3). A novel inulinolytic strain of Xanthomonas sp. has been reported that produces an endoinulinase optimally active at $45^{\circ} \mathrm{C}$ and $\mathrm{pH}=6$ (33). The optimal temperature of the purified enzyme from the marine yeast $C$. aureus G7a is reported to be $50{ }^{\circ} \mathrm{C}$ and the enzyme is very stable at up to $65^{\circ} \mathrm{C}(25)$. Therefore, inulinase produced by Xcp KM 24 seems to have considerable thermostability as compared to others reported in literature. However, the inulinase activity produced by $P$. guilliermondii strain 1 is the highest at $60^{\circ} \mathrm{C}$ and the enzyme is very stable at up to $60^{\circ} \mathrm{C}$ (26). Inulinase from terrestrial microorganisms in general shows the highest activity below $50^{\circ} \mathrm{C}$, whereas optimum temperature is mostly between 30 and $55^{\circ} \mathrm{C}(16,24,34,35)$. The optimum temperature for an endoinulinase from $B$. smithii $\mathrm{T} 7$ was $70{ }^{\circ} \mathrm{C}$, the $t_{1 / 2}$ of the endoinulinase was $9 \mathrm{~h}$ and $2.5 \mathrm{~h}$ at 70 and $80^{\circ} \mathrm{C}$, respectively (20).

\section{Optimum $\mathrm{pH}$ and $\mathrm{pH}$ stability of inulinase}

The inulinase activity was measured in the $\mathrm{pH}$ range of 4-10 in the buffers with the same ionic concentrations. The results indicate the enzyme to be optimally active at $\mathrm{pH}=6.0$ (Fig. 4). The activity of the purified enzyme was stable between $\mathrm{pH}=6.0-9.0$ (Fig. 5). After $2 \mathrm{~h}$ at $50{ }^{\circ} \mathrm{C}$, more than 40 and $45 \%$ of the residual activity remained at $\mathrm{pH}=6.0$ and 9.0, respectively. An extracellular endoinulinase purified from $X$. oryzae (9) was optimally active at $\mathrm{pH}=7.5$ and $50^{\circ} \mathrm{C}$ and stable over a $\mathrm{pH}$ range of 6.0-9.0. An exoinulinase of $83 \mathrm{kDa}$ was purified from Streptococcus salivarius with optimum $\mathrm{pH}=7.0$ (36). The inulin-inducible inulinase from Clostridium acetobutylicum was reported to be produced both extra- and intracellularly with the $\mathrm{pH}$ and temperature optima of 5.5 and $47^{\circ} \mathrm{C}$, respectively (37). The endoinulinase from Clostridium thermoautotrophicum was maximally active at $60{ }^{\circ} \mathrm{C}$ and neutral $\mathrm{pH}$ (38). The D-fructofuranosidase of Bifidobacterium infantis is a monomeric protein of $70 \mathrm{kDa}$ and possesses both inulinase and invertase activities (39), and the purified endoinulinase showed the optimum $\mathrm{pH}$ and temperature of 6.0 and $37^{\circ} \mathrm{C}$, respectively. The optimum $\mathrm{pH}$ for

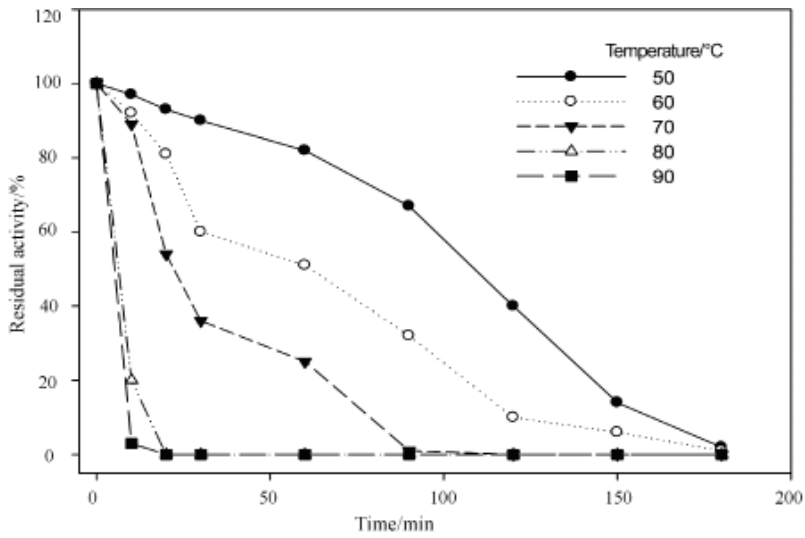

Fig. 3. Temperature stability of endoinulinase $(1 \mu \mathrm{M})$ of Xcp KM 24 mutant determined by incubating the enzyme at different temperatures $\left(50-90^{\circ} \mathrm{C}\right)$ 


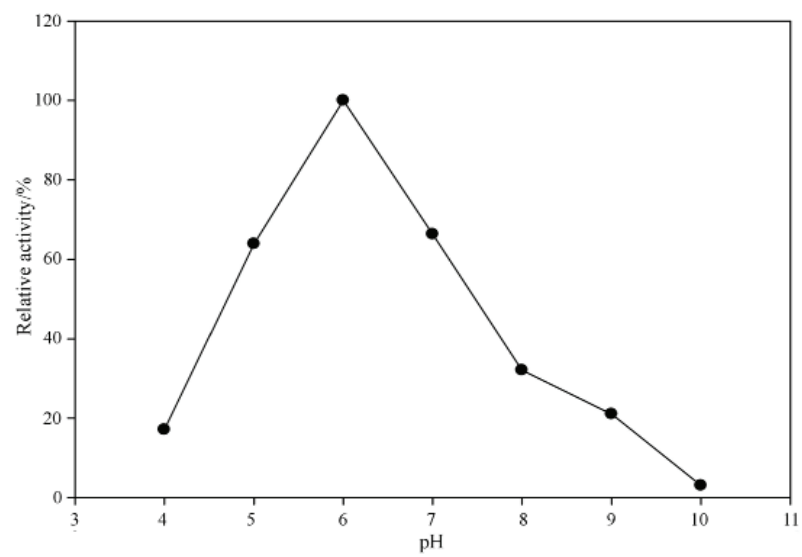

Fig. 4. Optimum $\mathrm{pH}$ for the purified endoinulinase determined by performing the standard enzyme assays at different $\mathrm{pH}$ values and $50{ }^{\circ} \mathrm{C}$

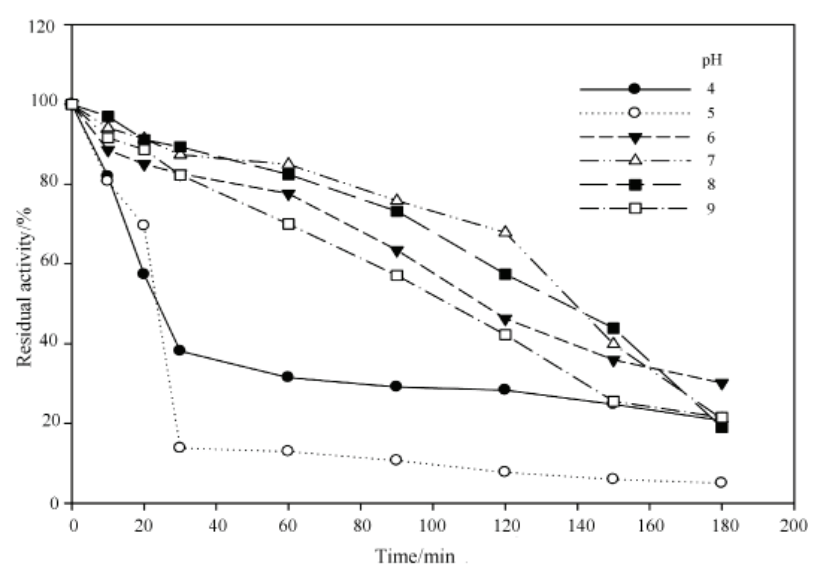

Fig. 5. $\mathrm{pH}$ stability of endoinulinase determined by incubating the enzyme at $\mathrm{pH}=4-9$ and $50{ }^{\circ} \mathrm{C}$ and performing the enzyme assay at $\mathrm{pH}=6.0$

an endoinulinase from B. smithii T7 was 4.5 and the enzyme was stable at $\mathrm{pH}=4.0-8.0(20)$. The gene encoding for one of the most thermostable bacterial inulinases, which retained $85 \%$ of its initial activity after $5 \mathrm{~h}$ at $80{ }^{\circ} \mathrm{C}$ and $\mathrm{pH}=7.0$, was cloned from Thermotoga maritima (40). The optimum $\mathrm{pH}$ values of the purified inulinases from fungi and yeast are in the range of 4.5-6.0 $(2,26,34,35)$.

\section{Kinetic properties of inulinase}

Enzymes are characterized by measuring their reactions with regard to their substrate affinities and maximal velocity rates. By measuring the rate of substrate utilization $(v)$ at different substrate concentrations [S], $K_{\mathrm{m}}$ and $v_{\max }$ can be calculated using Lineweaver-Burk, Eadie/Hofstee or Wilkinson methods $(41,42)$. In this study, the Lineweaver-Burk plots showed that the apparent $K_{\mathrm{m}}$ and $v_{\max }$ values of the inulinase when using inulin were $1.15 \mathrm{mg} /$ $\mathrm{mL}$ and $0.0000261 \mathrm{mg} /(\mathrm{mL} \cdot \mathrm{min})$, respectively (Fig. 6). The $k_{\text {cat }}$ value was found to be $0.145 \mathrm{~min}^{-1}$. The calculated catalytic efficiency of the enzyme was found to be $0.126 \mathrm{mg} /$ (mL·min). The $K_{\mathrm{m}}=1.15 \mathrm{mg} / \mathrm{mL}$ for this enzyme is lower than that of other reported inulinases, e.g. $K_{\mathrm{m}}$ values of the two endoinulinases, Endo-I and Endo-II, produced by $A$.

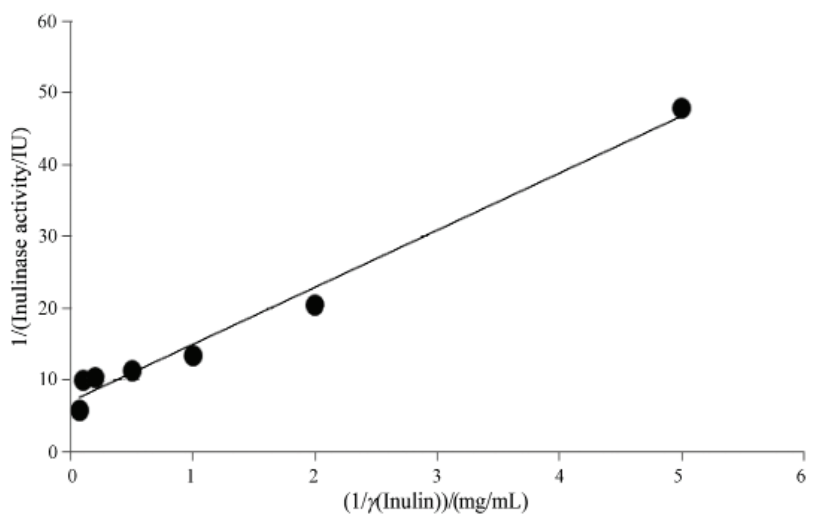

Fig. 6. Lineweaver-Burk plot for inulinase activity. Enzyme (1 $\mu \mathrm{M})$ was incubated with inulin $(0.2-15 \mu \mathrm{g} / \mathrm{mL})$ at $50{ }^{\circ} \mathrm{C}$ and $\mathrm{pH}=6.0$ for $20 \mathrm{~min}$. The reciprocal values of enzyme units $(1 / v)$ were plotted against the reciprocal values of the substrate concentrations $(1 /[\mathrm{S}])$, and the $K_{\mathrm{m}}$ values were determined by fitting the resulting data using ORIGIN v. 8 Pro. IU=inulinase unit (the amount of enzyme that produces $1 \mu \mathrm{mol}$ of fructose equivalent per min)

ficuum JNSP5-06 were 14.8 and $25.6 \mathrm{mg} / \mathrm{mL}$, respectively (21). A. ficuum JNSP5-06 endoinulinase was expressed in E. coli and the $K_{\mathrm{m}}$ and $v_{\max }$ values with inulin as the substrate were found to be $(67.4 \pm 4.2) \mathrm{mg} / \mathrm{mL}$ and $(349.2 \pm 13.7)$ $\mathrm{mg} /(\mathrm{mL} \cdot \mathrm{min})$, respectively $(22)$. The $K_{\mathrm{m}}$ value of inulinase from $P$. guilliermondii strain 1 using inulin as substrate was $21.1 \mathrm{mg} / \mathrm{mL}$ (43). Streptomyces sp. ALKC4 endoinulinase showed $K_{\mathrm{m}}(1.63 \mathrm{mM})$ and $v_{\max }(450 \mathrm{IU} / \mathrm{mg})$ using inulin as substrate, which is almost the same as the enzyme reported in this study (18). An endoinulinase from $B$. smithii T7 exhibited comparatively lower $K_{\mathrm{m}}(4.17 \mathrm{mM})$ and higher $v_{\max }$ (833 IU per mg of protein), which demonstrated that this endoinulinase has greater affinity for inulin substrate (20). Debaryomyces cantarelli (15 mM) (44), Candida salmenticensis (17 mM) (45) and A. ficuum (10-15 $\mathrm{mM}$ ) (19) showed higher $K_{\mathrm{m}}$ than the inulinase reported here, which makes it a better candidate for inulin hydrolysis. Because of lower $K_{\mathrm{m}}$ value and high thermal stability, Xcp KM 24 endoinulinase can be used for commercial applications like for large scale FOS (alternative sweetener) production, and can help reducing the overall production cost.

\section{Product of inulin hydrolysis by purified inulinase}

Thin layer chromatography analysis of products of inulin hydrolysis showed that oligosaccharides were the predominant end product during hydrolysis for $10 \mathrm{~min}$ to $2 \mathrm{~h}$ (Fig. 7). Oligosaccharides with various degrees of polymerization were observed in the samples after hydrolysis for 10 and $30 \mathrm{~min}$ or $2 \mathrm{~h}$ and this hydrolysis pattern suggests the presence of an active endoinulinase. The prolonged enzyme hydrolysis $(24 \mathrm{~h})$ did not result in any kind of mono- (glucose and fructose) or disaccharides (sucrose) in the hydrolysates, which pointed to the absence of exoinulinase activity of the enzyme (data not shown). However, the prolonged enzyme hydrolysis $(24 \mathrm{~h}$ ) by the crude extract reported in our previous study with this organism (7) revealed the production of mono- (glucose and fructose) or disaccharides (sucrose) in the hydrolysates, 


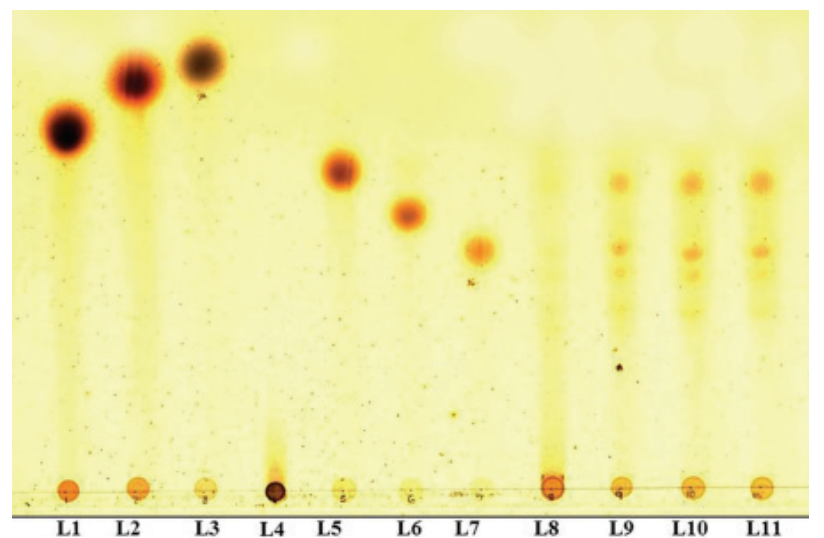

Fig. 7. Thin layer chromatography of reaction products formed during hydrolysis of inulin by purified inulinase from X. campestris KM 24. L1=sucrose, L2=glucose, L3=fructose, L4=inulin, L5=1-kestose, L6=1,1-kestotetraose, L7=1,1,1-kestopentaose, L8= enzyme+inulin $(0 \mathrm{~h}), \mathrm{L} 9=$ enzyme+inulin $(10 \mathrm{~min}), \mathrm{L} 10=$ enzyme + inulin (30 min), L11=enzyme+inulin (2 h)

which pointed to the presence of exoinulinase in the extract at low or undetectable levels, despite ammonium sulphate precipitation, with only endoinulinase activity observed. Inulin hydrolysis by an extracellular inulinase of Rhizopus sp. resulted in the production of fructose and oligosaccharides after $24 \mathrm{~h}$ of incubation (46). Fructose formation was completely absent when inulin was hydrolysed with crude endoinulinase of X. oryzae No. 5 (47). The native endoinulinase produced by Arthrobacter sp. S37 hydrolysed inulin at optimal $\mathrm{pH}=7.5$ and $50{ }^{\circ} \mathrm{C}$ mainly into inulotriose (F3), inulotetraose (F4) and inulopentaose (F5) (12). Inulobiose was the major product of the activity of immobilized endoinulinase produced by $P$ seudomonas sp. No. 65 or immobilized recombinant $E$. coli, possessing endoinulinase gene (48). In soluble form, the endoinulinase produced by Pseudomonas sp. No. 65 gave two major components, inulobiose and DP3 oligosaccharides (49). When inulooligosaccharide (IOS) from chicory juice was hydrolysed by an endoinulinase from Pseudomonas sp, the major reaction products were DP2, DP3 and DP4 (32). After the endoinulinase gene (inul) of Pseudomonas sp. was expressed in E. coli HB101, the intact cells of the recombinant $E$. coli and the native enzyme from Pseudomonas sp. were used to produce IOS. It was found that higher levels of inulobiose (the smallest molecule in the product) were observed when intact cells were used (49).

\section{Conclusions}

Inulin-hydrolysing enzymes (inulinases) are widely used in food and pharmaceutical industries. Endoinulinases hydrolyse the internal $\beta$-2,1-fructofuranosidic linkages to yield inulooligosaccharides such as inulotriose, inulotetraose and inulopentaose as their main products. We have reported previously the optimization of the nutritional and growth parameters for Xanthomonas campestris pv. phaseoli to enhance the endoinulinase and fructooligosaccharide (FOS) production through ethylmethanesulphonate mutagenesis of the organism and named it $X$. campestris pv. phaseoli, mutant KM 24 (Xcp KM 24). The present study, therefore, focused on the purification and characterization of endoinulinase from Xcp KM 24 using gel filtration chromatography. Since the importance and potential applications of FOS is growing globally, this endoinulinase could be used for commercial applications like for large scale FOS (alternative sweetener) production.

\section{Acknowledgement}

This study was supported by grants from Durban University of Technology and National Research Foundation (NRF), Republic of South Africa.

\section{References}

1. Yun JW. Fructooligosaccharides - occurrence, preparation and application. Enzyme Microb Technol. 1996;19:107-17. http://dx.doi.org/10.1016/0141-0229(95)00188-3

2. Singh RS, Singh RP. Production of fructooligosaccharides from inulin by endoinulinases and their prebiotic potential. Food Technol Biotechnol. 2010;48:435-50.

3. Deryeke DG, Vandamme EJ. Production and properties of Aspergillus niger inulinase. J Chem Technol Biotechnol. 1984; 34:45-51. http://dx.doi.org/10.1002/jctb.280340108

4. Singh P, Gill PK. Production of inulinases: Recent advances. Food Technol Biotechnol. 2006;44:151-62.

5. Mazutti M, Bender JP, Treichel H, Luccio MD. Optimization of inulinase production by solid-state fermentation using sugarcane bagasse as substrate. Enzyme Microb Technol. 2006;39:56-9.

http://dx.doi.org/10.1002/jctb.2273

6. Ayyachamy M, Khelawan K, Pillay D, Permaul K, Singh S. Production of inulinase by Xanthomonas campestris pv. phaseoli using onion (Allium cepa) and garlic (Allium sativum) peels in solid state cultivation. Appl Microbiol Lett. 2007;45:439-44.

http://dx.doi.org/10.1111/j.1472-765X.2007.02222.x

7. Naidoo K, Ayyachamy M, Permaul K, Singh S. Enhanced fructooligosaccharides and inulinase production by a Xanthomonas campestris pv. phaseoli KM 24 mutant. Bioprocess Biosyst Eng. 2009;32:689-95. http://dx.doi.org/10.1007/s00449-008-0293-6

8. Kamal FHM, Mahnaz MA, Seyed AM. Mutagenesis of Xanthomonas campestris and selection of strains with enhanced xanthan production. Iran Biomed J. 2003;7:91-8.

9. Cho YJ, Sinha J, Park JP, Yun JW. Production of inulooligosaccharides from chicory extract by endoinulinase from Xanthomonas oryzae No. 5. Enzyme Microb Technol. 2001;5:43945 . http://dx.doi.org/10.1016/S0141-0229(00)00341-0

10. Miller GL. Use of dinitrosalicylic acid reagent for determination of reducing sugar. Anal Chem. 1959;31:426-8. http://dx.doi.org/10.1021/ac60147a030

11. Laemmli UK. Cleavage of structural proteins during the assembly of the head of bacteriophage T4. Nature. 1970;227:680-5. http://dx.doi.org/10.1038/227680a0

12. Bradford MM. A rapid and sensitive method for the quantitation of microgram quantities of protein utilizing the principle of protein-dye binding. Anal Biochem. 1976;72:248-54. http://dx.doi.org/10.1016/0003-2697(76)90527-3

13. Kang SI, Chang YJ, Oh SJ, Kim SI. Purification and properties of an endo-inulinase from an Arthrobacter sp. Biotech- 
nol Lett. 1998;20:983-6.

http://dx.doi.org/10.1023/A:1005440910352

14. Kato K, Araki T, Kitamura T, Morita N, Moori M, Suzuki Y. Purification and properties of a thermostable inulinase ( $\beta$-Dfructan fructohydrolase) from Bacillus stearothermophilus KP1289. Starch-Stärke. 1999;51:253-8.

http://dx.doi.org/10.1002/(SICI)1521-379X(199907)51:7<253: :AID-TAR253>3.0.CO;2-7

15. Kochhar A, Gupta AK, Kaur N. Purification and immobilization of inulinase from Aspergillus candidus for producing fructose. J Sci Food Agric. 1999;79:549-54.

http://dx.doi.org/10.1002/(SICI)1097-0010(19990315)79:4<549: :AID-JSFA216>3.0.CO;2-0

16. Kushi RT, Monti R, Contiero J. Production, purification and characterization of an extracellular inulinase from Kluyveromyces marxianus var. bulgaricus. J Ind Microbiol Biotechnol. 2000;25:63-9. http://dx.doi.org/10.1038/sj.jim.7000032

17. Nakamura T, Shitara A, Matsuda S, Matsuo T, Suiko M, Ohta K. Production, purification and properties of an endoinulinase of Penicillium sp. TN-88 that liberates inulotriose. J Ferment Bioeng. 1997;84:313-8. http://dx.doi.org/10.1016/S0922-338X9789250-1

18. Sharma AD, Gill PK. Purification and characterisation of heat-stable exo-inulinase from Streptomyces sp. J Food Eng. 2007;79:1172-8. http://dx.doi.org/10.1016/j.jfoodeng.2006.04.008

19. Ettalibi M, Baratti JC. Purification, properties and comparison of invertase, exoinulinases and endoinulinases of Aspergillus ficuum. Appl Microbiol Biotechnol. 1987;26:13-20. http://dx.doi.org/10.1007/BF00282143

20. Gao W, Bao Y, Liu Y, Zhang X, Wang J, An L. Characterization of thermostable endoinulinase from a new strain Bacillus smithii T7. Appl Biochem Biotechnol. 2009;157: 498-506. http://dx.doi.org/10.1007/s12010-008-8313-1

21. Chen H, Chen X, Li Y, Wang J, Jin Z, Xu X, et al. Purification and characterisation of exo- and endo-inulinase from Aspergillus ficuum JNSP5-06. Food Chem. 2009;115:1206-12. http://dx.doi.org/10.1016/j.foodchem.2009.01.067

22. Chen $X, X u X$, Jin $Z, C$ Chen $H$. Expression of an endoinulinase from Aspergillus ficuum JNSP5-06 in Escherichia coli and its characterization. Carbohydr Polym. 2012;88:748-53. http://dx.doi.org/10.3109/1040841X.2012.694411

23. Pouyez J, Mayard A, Vandamme A, Roussel G, Wouters J, Housen I, et al. First crystal structure of an endo-inulinase, INU2, from Aspergillus ficuum: Discovery of an extra-pocket in the catalytic domain responsible for its endo-activity. Biochimie. 2012;94:2423-30.

http://dx.doi.org/10.1016/j.biochi.2012.06.020

24. Pandey A, Fontana JD, Krieger N, Selvakumar P, Soccol CR, Soccol VT. Recent developments in microbial inulinases: Its production, properties and industrial applications. Appl Biochem Biotechnol. 1999;81:35-52. http://dx.doi.org/10.1385/ABAB:81:1:35

25. Sheng J, Chi ZM, Yan KR, Wang XJ, Gong F, Li J. Use of response surface methodology for optimizing process parameters for high inulinase production by the marine yeast Cryptococcus aureus G7a in solid-state fermentation and hydrolysis of inulin. Bioprocess Biosyst Eng. 2009;32:333-9. http://dx.doi.org/10.1007/s00449-008-0252-2

26. Gong F, Chi M, Sheng J, Li J, Wang X. Purification and characterization of extracellular inulinase from a marine yeast Pichia guilliermondii and inulin hydrolysis by the purified inulinase. Biotechnol Bioprocess Eng. 2008;13:533-9. http://dx.doi.org/10.1007/s12257-007-0177-7

27. Kwon HJ, Kim HY, Choi YJ. Cloning and characterisation of Pseudomonas mucidolens exoinulinase. J Microbiol Biotechnol. 2000;10:238-43.
28. Tsujimoto Y, Watanabe A, Nakano K, Watanabe K, K Matsui, $\mathrm{K}$ Tsuji. Gene cloning, expression and crystallization of a thermostable exoinulinase from Geobacillus stearothermophilus KP1289. Appl Microbiol Biotechnol. 2003;62:180-5. http://dx.doi.org/10.1007/s00253-003-1261-3

29. Zhang S, Yang F, Wang Q, Hua Y, Zhao ZK. High-level secretory expression and characterization of the recombinant Kluyveromyces marxianus inulinase. Process Biochem. 2012;47: $151-5$. http://dx.doi.org/10.1016/j.procbio.2011.10.002

30. Li Y, Liu G, Wang K, Chi Z, Madzak C. Overexpression of the endo-inulinase gene from Arthrobacter sp. S37 in Yarrowia lipolytica and characterization of the recombinant endo-inulinase. J Mol Catal B: Enzyme. 2012;74:109-15. http://dx.doi.org/10.1016/j.molcatb.2011.09.006

31. Kuzuwa S, Yokoi K, Kondo M, Kimoto H, Yamakawa A, Taketo A. Properties of the inulinase gene levH1 of Lactobacillus casei IAM 1045; cloning, mutational and biochemical characterization. Gene. 2012;495:154-62. http://dx.doi.org/10.1016/j.gene.2011.12.004

32. Meenakshi S, Umayaparvathi S, Manivasagan P, Arumugam M, Balasubramanian T. Purification and characterization of inulinase from marine bacterium Bacillus cereus MU-31. Indian J Geo-Marine Sci. 2013;424:510-5.

33. Park JP, Bae JT, You DJ, Kim BW, Yun JW. Production of inulooligosaccharides from inulin by a novel endoinulinase from Xanthomonas sp. Biotechnol Lett. 1999;21:1043-46. http://dx.doi.org/10.1023/A:1005632526442

34. Zhang L, Zhao C, Wang J, Ohta Y, Wang Y. Inhibition of glucose on an exoinulinase from Kluyveromyces marxianus expressed in Pichia pastoris. Process Biochem. 2005;40:154145 . http://dx.doi.org/10.1016/j.procbio.2004.01.057

35. Singh R, Sooch BS, Puri M. Optimisation of medium and process parameters for the production of inulinase from a newly isolated Kluyveromyces marxianus YS-1. Bioresour Technol. 2007;98:2518-22. http://dx.doi.org/10.1007/s10295-007-0237-1

36. Takahashi N, Mizuno F, Takamori K. Purification and preliminary characterization of exo- $\beta$-D-fructosidase in Streptococcus salivarius KTA-19. Infect Immunol. 1985;47:271-6.

37. Looten P, Blanchet PD, Vandecasteele JP. The $\beta$-fructofuranosidase activities of a strain of Clostridium acetobutylicum grown on inulin. Appl Microbiol Biotechnol. 1987;25:419-25. http://dx.doi.org/10.1007/BF00253311

38. Drent WJ, Gottschal JC. Fermentation of inulin by a new strain of Clostridium thermoautotrophicum isolated from Dahlia tubers. FEMS Microbiol Lett. 1991;78;285-92. http://dx.doi.org/10.1111/j.1574-6968.1991.tb04457.x

39. Warchol M, Perrin S, Grill JP, Schneider F. Characterisation of a purified $\beta$-fructofuranosidase from Bifidobacterium infantus ATCC 15697. Lett. Appl Microbiol 2002;35:462-7. http://dx.doi.org/10.1046/j.1472-765X.2002.01224.x

40. Liebl W, Brem D, Gotschlich A. Analysis of the gene for $\beta$-fructosidase invertase, inulinase of the hyperthermophilic bacterium Thermotoga maritima and characterization of the enzyme expressed in Escherichia coli. Appl Microbiol Biotechnol. 1998;50:55-64. http://dx.doi.org/10.1007/s002530051256

41. Lineweaver $\mathrm{H}$, Burk $\mathrm{D}$. The determination of enzyme dissociation constants. J Am Chem Soc. 1934;56:658-66. http://dx.doi.org/10.1021/ja01318a036

42. Counotte GHM, Prins RA. Calculation of $K_{m}$ and $V_{\max }$ from substrate concentration versus time plot. Appl Environ Microbiol. 1979;38:758-60.

43. Zhang T, Gong F, Chi Z, Sheng J, Li J, Wang X. Cloning and characterisation of the inulinase gene from a marine yeast 
Pichia guilliermondii and its expression in Pichia pastoris. Anton Leeuw Int J G. 2009;95:13-22. http://dx.doi.org/10.1007/s10482-008-9281-8

44. Beluche I, Guiraud JP, Galzy P. Inulinase activity of Debaromyces cantarelli, Folia Microbiol Praha. 1980;25:32-9. http://dx.doi.org /10.1007/BF02876395

45. Guiraud JP, Viard-Gaudin C, Galzy P. Inulinase of Candida salmanticensis, Agric Biol Chem. 1980;44:1245-52. http://dx.doi.org/10.1271/bbb1961.44.1245

46. Ohta K, Suetsugu N, Nakamura T. Purification and properties of an extracellular inulinase from Rhizopus sp. strain TN-96. J Biosci Bioeng. 2002;94:78-80. http://dx.doi.org/10.1016/S1389-17230280120-7
47. Cho YJ, Yun JW. Purification and characterization of endoinulinase from Xanthomonas oryzae No 5, Process Biochem. 2002;5:1325-31.

http://dx.doi.org/10.1016/S0032-95920200018-3

48. Yun JW, Kim DH, Uhm TB, Song SK. Production of highcontent inulo-oligosaccharides from inulin by a purified endoinulinase. Biotechnol Lett. 1997;19:935-8. http://dx.doi.org/10.1023/A:1018366410586

49. Yun JW, Choi YJ, Song CH, Song SK. Microbial production of inulo-oligosaccharides by an endoinulinase from Pseudomonas sp. expressed in Escherichia coli. J Biosci Bioeng. 1999;81:291-5.

http://dx.doi.org/10.1016/S1389-17239980034-6 